\title{
Program Exercise Sebagai Upaya Pencegahan COVID 19 ${ }^{1}$ Lini Dewi Mahesti, ${ }^{2}$ Dessy Triana Ramadhani, ${ }^{3}$ Atika Zulhidah Hasan, ${ }^{4}$ Hana Laila Nabilah, ${ }^{5}$ Muhammad Faris Fatahilah \\ Program Studi Fisioterapi, Fakultas Ilmu Kesehatan, Universitas Muhammadiyah Surakarta
} Jl. A. Yani Tromol Pos I Pabelan Kartasura Telp. (0271) 717417 Fax. (0271) 715448 Surakarta 57162

Email : j120180155@student.ums.ac.id

Tanggal Submisi: 20 Desember 2020; Tanggal Penerimaan: 03 Desember 2021

\begin{abstract}
ABSTRAK
Latar Belakang: Corona virus disease 2019 (COVID-19) merupakan penyakit menular yang disebabkan oleh jenis virus coronavirus yang baru ditemukan. Virus ini baru ditemukan pada Bulan Desember 2019 di Kota Wuhan, Tiongkok. Penyebaran yang sangat cepat menyebabkan seluruh negara menerapkan sistem lockdown. Penerapan peraturan semasa pandemi ini akan cenderung membentuk pola hidup sedenter pada masyarakat. Pola hidup sedenter akan menurunkan aktivitas fisik yang berpotensi mengakibatkan tubuh menjadi rentang terserang penyakit. Pada kondisi pandemi COVID-19, melakukan exercise perlu dijadikan sebuah budaya. Namun, pada kenyataannya bukti terkait exercise yang dapat meningkatkan imunitas tubuh masih sangat kurang. Metode: Metode yang digunakan dalam penelitian ini adalah Metode Kualitatif dengan pengambilan subjek penelitian secara acak. Jenis penelitian merupakan deskriptif analitis. Penelitian dilakukan dalam jangka waktu satu bulan yaitu pada bulan Mei hingga Juni 2020. Hasil: Penelitian menunjukkan adanya pengaruh melakukan exercise dengan peningkatan imunitas tubuh. Kesimpulan: Melakukan exercise dengan tipe aerobik moderate mampu meningkatkan sistem imun tubuh selama masa pandemi COVID-19 dan dapat dijadikan sebuah upaya pencegahan agar tubuh tidak mudah terpapar virus COVID-19.
\end{abstract}

Kata kunci: COVID-19, exercise, aktivitas fisik, sistem imun

\begin{abstract}
Background: Corona virus disease 2019 (COVID-19) is an infectious disease caused by a newly discovered type of coronavirus. This virus was only discovered in December 2019 in Wuhan City, China. The spread is very fast causing all countries to implement a lockdown system. The application of this regulation during a pandemic will tend to form a sedentary lifestyle in the community. A sedentary lifestyle will reduce physical activity that has the potential to cause the body to become vulnerable to disease. In the conditions of the COVID-19 pandemic, doing exercise needs to be a culture. However, in reality the evidence related to exercise that can increase body immunity is still lacking. Method: The method used in this study is a qualitative method by taking research subjects randomly. This type of research is descriptive analytical. The study was conducted over a period of one month, from May to June 2020. Results: The study showed that exercise had an effect on increasing body immunity. Conclusion: Doing moderate aerobic exercise can improve the body's immune system during the COVID-19 pandemic and can be used as a preventive measure so that the body is not easily exposed to the COVID-19 virus.
\end{abstract}

Keywords: COVID-19, exercise, physical activity, immune system 


\section{Pendahuluan}

COVID-19 adalah penyakit menular yang disebabkan oleh jenis virus coronavirus yang baru ditemukan. Virus ini baru ditemukan pada Bulan Desember 2019 di Kota Wuhan, Tiongkok. Saat ini virus corona telah menyebar ke seluruh lapisan dunia, dan WHO telah menetapkan coronavirus ini sebagai pandemic. Terhitung 28 April 2020, individual yang terjangkit virus COVID-19 per 29 April 2020 secara global \pm 3.11 juta, dengan kasus sembuh 926.000 dan kasus kematian 217.000 sedangkan di Indonesia, kasus terkonfirmasi 9.511, kasus sembuh 1.254, dan kasus kematian 773 (wikipedia). Berdasarkan data tersebut, diperhatikan data dari awal tersebarnya virus ini, menunjukan bahwa virus ini merupakan virus yang sangat cepat menyebar, namun kasus kematian dan kasus sembuh yang telah terkonfirmasi membuktikan pula bahwa virus ini masih dapat disembuhkan dan dapat dicegah.

Manifestasi Klinik dari COVID-19 yaitu demam (89\%), batuk (68\%), dyspnea (19\%), myalgia (38\%), produksi sputum (34\%) dan diare. Per 29 April 2020, rata-rata angka kematian mencapai hingga 19\%. Rata-rata angka sembuh mencapai hingga $81 \%$. Rata- rata pasien yang masuk Intensive care unit (ICU) sekitar $3 \%$ (worldometers). Setengah pasien yang telah masuk rumah sakit (97\%) akan membutuhkan oxygen therapy. Berdasarkan beberapa data, individual dengan risiko tertinggi terhadap infeksi severe COVID-19 disease yang memerlukan perawatan rumah sakit dan ICU adalah orang lanjut usia, pria, memiliki setidaknya satu kali co-existing comorbidity, memiliki skor penyakit yang serius (diukur melalui skor SOFA), peningkatan tingkatan ddimer dan/atau lymphocytopenia.

Penyebaran COVID-19 terbilang sangat cepat, virus ini dapat menyebar dari orang ke orang melalui percikan droplet dari hidung atau mulut dan juga melalui airbone. Percikan droplet kemudian jatuh ke benda-benda dan permukaan. Sedangkan, airbone akan melayang diudara bebas. Orang yang menyentuh benda atau permukaan yang terjangkit droplet ataupun airbone lalu menyentuh mata, hidup atau mulutnya maka dapat terjangkit COVID-19. Oleh karena itu penting bagi kita untuk menjaga jarak lebih dari 1 meter dari orang yang sakit, memakai masker ketika sedang berada diluar, melakukan aktivitas fisik dan mencuci tangan setiap 3 jam sekali sebagai upaya pencegahan terhadap COVID-19.

Melakukan exercise disamping menjadikan tubuh bugar, juga dapat memperlancar proses metabolisme tubuh sehingga menjadikan tubuh tidak mudah terjangkit patogen asing. Kondisi pandemi saat ini, mengharuskan ketika melakukan exercise diluar rumah harus mengikuti beberapa protokol kesehatan yang dianjurkan oleh pemerintah, untuk itu dibandingkan dengan exercise diluar rumah, melakukan exercise di rumah menjadi pilihan yang lebih efisien disaat pandemik saat ini. Melakukan exercise dirumah tidak harus yang berat namun banyak exercise sederhana yang dapat dilakukan, salah satunya exercise yang dapat dilakukan adalah dancing aerobic dengan mencontoh gerakan dari youtube.

\section{Metode Penelitian}

Metode yang digunakan dalam penelitian ini adalah Metode Kualitatif, yaitu suatu metode dalam meneliti sekelompok manusia, suatu objek, suatu kondisi, suatu sistem pemikiran, fenomena atau gejala-gejala kehidupan. Jenis penelitian merupakan deskriptif analitis. Penelitian dilakukan dalam jangka waktu satu bulan yaitu pada bulan Mei hingga Juni 2020.

Pengumpulan data dan informasi dilakukan melalui penelusuran yang bersumber pada artikel, buku teks, buku elektronik (ebook), hasil penelitian, jurnal penelitian, artikel ilmiah nasional dan internasional dalam rentang 
waktu publikasi 10 tahun. Kata kunci yang digunakan antara lain COVID-19, exercise, sistem imun, dan aktivitas fisik. Karakter sumber yang digunakan full-text dengan sumber relevan dan sesuai dengan judul tulisan dengan dasar pencarian didapatkan dari jurnal publikasi.

Informasi dan data berupa data sekunder yang diperoleh dari World Health Organization (WHO), World Confederation Physical Therapy (WCPT), Kementerian Kesehatan Republik Indonesia, Situs resmi pengkajian COVID-19 dan jurnal-jurnal penelitian terkait yang berbentuk panduan, penelitian dan ekperimen.

Subjek penelitian diambil secara acak berdasarkan kriteria inklusi. Kriteria inklusi adalah karakteristik umum subjek penelitian dari suatu populasi target yang terjangkau yang sudah diteliti :

1.Penelitian yang berfokus terhadap masyarakat Indonesia yang berisiko terjangkit COVID-19.

2.Penelitian yang berfokus pada program exercise untuk pecegahan COVID-19

3.Panduan manajemen pencegahan COVID-19 yang digunakan secara Internasional

4. Subjek penelitian adalah usia produktif 15 tahun - 45 tahun.

5.Penelitian mengenai pencegahan COVID-19 menggunakan teknik intervensi exercise.

Penelitian ini dilakukan dengan menggunakan instrumen berupa alat tulis dan komputer yang digunakan untuk menulis, mencatat dan melaporkan hasil telaah sumbersumber yang relevan.

Informasi dan data mengenai manfaat aktivitas fisik untuk pencegahan COVID-19 didapatkan melalui:

1.Mencari sumber-sumber relevan terkait yaitu dengan mencari informasi dan pembahasan yang berhubungan dengan topik yang dibahas.

2.Menelaah sumber-sumber yang diperoleh kemudian dianalis untuk diambil intisari sesuai dengan topik pembahasan.

3.Membandingkan dan menggabungkan informasi yang didapatkan dari beberapa sumber.

4. Menyusun informasi berdasarkan sumbersumber relevan yaitu Informasi dan data yang telah digolongkan berdasarkan karakteristik akan diolah dan dianalisis secara objektif dan sistematis sesuai dengan permasalahan yang akan dibahas. Kemudian informasi yang diperoleh akan disintesis untuk diambil intisari berdasarkan fakta yang terdapat dalam hasil penelitian atau sebagai referensi untuk menjawab rumusan masalah.

\section{Hasil}

Meliputi penyajian data/informasi yang Persebaran virus Covid-19 kian merebak diseluruh belahan dunia, termasuk Indonesia. Berdasarkan data statistik perkembangan virus covid-19, terhitung hingga 05 November 2020 terdapat kasus positif sebanyak $\pm 48,6$ juta penduduk dengan $\pm 34,8$ juta penduduk yang sembuh dan $\pm 1,2$ juta penduduk yang meninggal dunia. Sementara di Indonesia, telah tercatat kasus positif covid-19 sebanyak \pm 425.796 penduduk dengan \pm 357.142 penduduk yang sembuh dan \pm 14.348 penduduk Indonesia yang meninggal dunia (worldometer). Angka tersebut cenderung mengalami kenaikan sejak merebaknya virus covid-19 pada Januari 2020. Berikut merupakan hasil penyajian data penelitian dalam bentuk deskripsi tabel. 
Tabel 1. Data Literatur Review

\begin{tabular}{|c|c|c|c|c|}
\hline Judul/author & Tujuan & Metode & Hasil & kesimpulan \\
\hline $\begin{array}{l}\text { Physical exercise as a tool to } \\
\text { help the immune system } \\
\text { against COVID-19: an } \\
\text { integrative review of the } \\
\text { current literature/ Matheus } \\
\text { Pelinski da } \\
\text { Silveira, Kimberly Kamila } \\
\text { da Silva Fagundes, Matheus } \\
\text { Ribeiro } \\
\text { Bizuti, Édina Starck, Renata } \\
\text { Calciolari Rossi \& Débora } \\
\text { Tavares de Resende e Silva } \\
\text { (2020) }\end{array}$ & $\begin{array}{l}\text { Membuktikan } \\
\text { infeksi pernafasan virus akut } \\
\text { yakni coronavirus } 2 \text { (SARS- } \\
\text { CoV-2) dan penyakit } \\
\text { coronavirus } 2019 \text { (COVID- } \\
\text { 19) yang di hubungkan dengan } \\
\text { respon imun. }\end{array}$ & $\begin{array}{l}\text { Literatur } \\
\text { review }\end{array}$ & $\begin{array}{l}\text { Masih terdapat kesenjangan pengetahuan tentang } \\
\text { mekanisme patogen yang terlibat dalam infeksi } \\
\text { SARS-CoV-2. Akan tetapi, terdapat konsensus dalam } \\
\text { literatur ilmiah tentang keterlibatan penting sistem } \\
\text { kekebalan dalam kerentanan, perkembangan, dan } \\
\text { hasil COVID-19. } \\
\text { Ketidak seimbangan dalam respon imun bawaan dan } \\
\text { adaptif yang utama ditandai oleh perubahan seperti } \\
\text { badai sitokin dan limfopenia, selain gangguan pada } \\
\text { koagulasi dan kondisi terkait host, termasuk obesitas, } \\
\text { sindrom metabolik dan penuaan (imunosenescence), } \\
\text { adalah salah satu faktor yang terkenal. terkait dengan } \\
\text { prognosis } \\
\text { infeksi yang lebih buruk. }\end{array}$ & $\begin{array}{l}\text { exercise teratur dengan } \\
\text { intensitas yang disarankan } \\
\text { menjadi alat bantu dalam } \\
\text { memperkuat } \\
\text { kekebalan untuk COVID- } \\
19 .\end{array}$ \\
\hline $\begin{array}{l}\text { Promising effects of exercise } \\
\text { on the cardiovascular, } \\
\text { metabolic and immune } \\
\text { system during COVID-19 } \\
\text { period/Isley Jesus, Valentin } \\
\text { Vanhee, Therese B. } \\
\text { Deramaudt, Marcel Bonay } \\
(2020)\end{array}$ & $\begin{array}{l}\text { Membuktikan efek exercise } \\
\text { mampu meningkatkan } \\
\text { kardiorespirasi }\end{array}$ & $\begin{array}{l}\text { Literatur } \\
\text { review }\end{array}$ & $\begin{array}{l}\text { Hubungan langsung metabolik dan endokrin antara } \\
\text { diabetes mellitus tipe } 2 \text { (DMT2), hipertensi, dan } \\
\text { coronavirus SARSCoV-2 (COVID-19) telah } \\
\text { dibuktikan. Dengan dilakukannya exercise mampu } \\
\text { meningkatkan sistem imun dan membantu } \\
\text { pencegahan penyakit tersebut. Efek akut dan kronis } \\
\text { dari exercise pada respon kekebalan telah dipelajari } \\
\text { secara ekstensif pada atlet. Exercise berlebihan, } \\
\text { mengakibatkan peningkatan risiko penyakit, yang } \\
\text { dikaitkan dengan disfungsi kekebalan dan menekan } \\
\text { imunoglobulin, penurunan aktivitas sel pembunuh } \\
\text { alami dan penurunan fungsi sel T dan } \\
\text { B. Sebaliknya, pada exercise tipe sedang akan } \\
\text { memberi efek menguntungkan untuk mencegah }\end{array}$ & $\begin{array}{l}\text { Exercise tipe sedang } \\
\text { bermanfaat ganda pada } \\
\text { Diabetes Militus tipe } 2 \text { dan } \\
\text { penyakit } \\
\text { kardiovaskular untuk } \\
\text { mencegah peradangan dan } \\
\text { infeksi virus pada } \\
\text { pernapasan, termasuk infeksi } \\
\text { virus corona. }\end{array}$ \\
\hline
\end{tabular}




\begin{tabular}{|c|c|c|c|c|}
\hline & & & $\begin{array}{l}\text { kanker dan perkembangan penyakit kardiovaskular. } \\
\text { Sel Imun dalam respons anti- inflamasi terkait } \\
\text { dengan oksidasi asam lemak mitokondria akan } \\
\text { memperbaiki respirasi dalam sel mononuklear darah. } \\
\text { Studi observasional aktivitas volume rendah, } \\
\text { mengurangi semua penyebab mortalitas 14\%, } \\
\text { mortalitas kanker } 10 \% \text {, dan mortalitas dari penyakit } \\
\text { kardiovaskular sebesar } 20 \% \text {, dibandingkan dengan } \\
\text { individu } \\
\text { dalam kelompok tidak aktif. }\end{array}$ & \\
\hline $\begin{array}{l}\text { The COVID-19 pandemic and } \\
\text { physical activity/ Woods, } \\
\text { Jeffrey A. Hutchinson, Noah } \\
\text { T. Powers, Scott K. Roberts, } \\
\text { William O. Gomez-Cabrera, } \\
\text { Mari Carmen Radak, Zsolt } \\
\text { Berkes, Istvan Boros, Anita } \\
\text { Boldogh, Istvan } \\
\text { Leeuwenburgh, Christiaan } \\
\text { Coelho-Júnior, Hélio José } \\
\text { Marzetti, Emanuele Cheng, } \\
\text { Ying Liu, Jiankang Durstine, } \\
\text { J. Larry Sun, } \\
\text { Junzhi Ji, Li Li (2020) }\end{array}$ & $\begin{array}{l}\text { Mengetahui ancaman Covid- } 19 \\
\text { terhadap kerusakan sistem } \\
\text { fisiologi manusia, Mengatasi } \\
\text { bahaya ketidakaktifan fisik } \\
\text { terkait wabah virus corona, } \\
\text { memberikan rekomendasi } \\
\text { strategi untuk mengurangi } \\
\text { potensi kerusakan terutama } \\
\text { dampaknya terhadap sistem } \\
\text { kekebalan tubuh }\end{array}$ & $\begin{array}{l}\text { Literatur } \\
\text { review }\end{array}$ & $\begin{array}{l}\text { Exercise merupakan solusi yang tepat untuk } \\
\text { mengatasi bahaya ketidakaktifan selama pandemi } \\
\text { covid-19, namun perlu diperhatikan seseorang yang } \\
\text { terjangkit covid-19 untuk melakukan exercise, karena } \\
\text { ancaman kardiovaskuler yang tinggi sehingga perlu } \\
\text { diperhatikan intensitas dalam melakukan exercise. }\end{array}$ & $\begin{array}{l}\text { Exercise } \\
\text { diperlukan dalam kondisi } \\
\text { pandemic seperti ini } \\
\text { karena akibat dari } \\
\text { pandemic menyebabkan } \\
\text { seseorang menjadi tidak } \\
\text { aktif dalam beraktivitas } \\
\text { yang akan memberikan } \\
\text { efek pada sistem respirasi, } \\
\text { kardiovaskuler, } \\
\text { muskuloskletal. }\end{array}$ \\
\hline
\end{tabular}




\begin{tabular}{|c|c|c|c|c|}
\hline $\begin{array}{l}\text { Physical activities, exercises, } \\
\text { and their effects to the } \\
\text { immune system/ } \\
\text { Nurmasitoh, Titis (2015) }\end{array}$ & $\begin{array}{l}\text { Membuktikan keteraitan antara } \\
\text { exercise dan aktifitas fisik } \\
\text { terhadap peningkatan sistem } \\
\text { kekebalan tubuh manusia. }\end{array}$ & $\begin{array}{l}\text { Literatur } \\
\text { Review }\end{array}$ & $\begin{array}{l}\text { hubungan antara aktivitas fisik dan berolahraga } \\
\text { dengan sistem kekebalan. Berdasarkan kurva } \\
\text { berbentuk } \mathrm{J} \text {, orang yang melakukan senam ringan } \\
\text { dan aktivitas fisik memiliki risiko lebih rendah } \\
\text { infeksi saluran pernafasan dibandingkan dengan } \\
\text { mereka yang tidak aktif dan latihan intensitas tinggi. } \\
\text { Orang yang terbiasa latihan intensitas sedang }\end{array}$ & $\begin{array}{l}\text { Exercise rutin dan aktivitas } \\
\text { fisik dengan intensitas } \\
\text { sedang akan meningkatkan } \\
\text { sistem kekebalan tubuh } \\
\text { terhadap infeksi. }\end{array}$ \\
\hline & & & $\begin{array}{l}\text { secara rutin akan meningkat kondisi psikologis, } \\
\text { menurunkan emosi stres, meningkatkan status gizi, } \\
\text { dan meningkatkan kebiasaan tidur. Efek positif dari } \\
\text { kondisi tersebut secara tidak langsung akan } \\
\text { meningkatkan sistem kekebalan dan mengurangi } \\
\text { risiko infeksi. } \\
\text { Orang yang melakukan latihan intensitas tinggi akan } \\
\text { mengalami kondisi dimana sistem kekebalan } \\
\text { mengalami depresi setelah berolahraga. Ini akan } \\
\text { memungkinkan virus dan bakteri menyerang tubuh } \\
\text { manusia, maka risiko infeksi akan meningkat lebih } \\
\text { tinggi. Mekanisme biologis terkait dengan hormon } \\
\text { stres, Kortisol. Exercise dengan intensitas tinggi } \\
\text { memiliki kortisol yang lebih tinggi. Kortisol } \\
\text { memiliki sifat imunosupresif dan akan menghambat } \\
\text { fungsi sitokin dan sel NK, serta mengurangi produksi } \\
\text { limfosit T dan mengubah fungsinya. }\end{array}$ & \\
\hline
\end{tabular}




\section{Pembahasan}

Berdasarkan review jurnal dan artikel diatas, didapatkan hasil bahwa exercise tipe sedang (moderate) mampu untuk meningkatkan sistem imun pada tubuh manusia dengan menghasilkan beberapa macam perubahan fisiologis sebagai bentuk perlawanan terhadap infeksi covid-19 yang telah dijelaskan pada jurnal. Secara khusus, setiap exercise aerobik mampu meningkatkan aktivitas anti-patogen makrofag jaringan dengan peningkatan resirkulasi imunoglobulin, sitokin anti inflamasi, neutrofil, sel B imatur dan sel pembunuh alami (NK), dan sel CD8+T. Dengan exercise rutin, perubahan akut ini akan meningkatkan aktivitas kekebalan imun, kekebalan regulasi, dan kesehatan metabolik. Sehingga efek yang akan dihasilkan latihan ini adalah fungsi aktif kekebalan bagi mereka yang rentan infeksi COVID-19.

Exercise awal dalam rangka pencegahan COVID-19 bisa dengan selama 2-10 menit dengan pengulangan sebanyak 3 kali setiap gerakan. Seiring berjalannya kebiasaan melakukan exercise maka dosis latihan dapat ditingkatkan sesuai dengan kemampuan. Minimal durasi melakukan exercise rutin adalah 75 menit/minggu dengan selang waktu 2 hari sekali agar tubuh memiliki jeda waktu untuk melakukan relaksasi. Bisa dilakukan sehari selama 25 menit. Beberapa exercise yang dapat dilakukan berdasarkan rekomendasi World Health Organization (WHO) dan ACSM diantaranya adalah :

\section{Interval walking}

Latihan ini dilakukan dengan jalan cepat-lambat secara bergantian setiap 6 meter dengan Jarak $1.2 \mathrm{~km}$ dengan interval istirahat 30 detik setiap 30 meter. Latihan ini dapat dilakukan sesuai kemampuan dan secara bertahap dapat ditambahkan untuk jaraknya.

\section{Step-up}

Latihan ini dapat dilakukan sebanyak 10 kali dan pengulangan sebanyak 3 kali dengan interval istirahat 30 detik setiap jedanya.

\section{Squat}

Gerakan ini bisa dilakukan sebanyak 10 kali dengan pengulangan sebanyak 3 kali dan interval istirahat 30 detik setiap jedanya

\section{Push-up}

Latihan ini bisa dilakukan secara berulang sebanyak 10 kali dengan 3 kali pengulangan dan jeda istirahat selama 30 detik setiap sesi.

\section{Plank}

Latihan ini bisa dilakukan dengan mempertahankan posisi selama 15 detik. Ulangi sebanyak 3 kali dan tingkatkan durasi plank secara berkala.

\section{Kesimpulan dan Saran}

Hasil kesimpulan penelitian ini yakni dengan pengumpulan berbagai macam sumber penelitian terdahulu membuktikan bahwa Melakukan exercise dengan tipe aerobik moderate mampu meningkatkan sistem imun tubuh selama masa pandemi COVID-19 dan dapat dijadikan sebuah upaya pencegahan agar tubuh tidak mudah terpapar virus COVID-19.

Penulis memberikan saran dengan harapan dapat memberi manfaat kepada peneliti, mahasiswa, dan masyarakat. Saran yang diberikan yaitu melakukan exercise secara rutin di rumah, sebagai bentuk peningkatan imun tubuh dan langkah pencegahan terkena paparan virus ataupun patogen lain.

\section{Daftar Pustaka}

Chandra,Cindy Calista., Purwoko,Yosef., Widodo,Sumardi., Sumekar,Tanjung Ayu. (2019). Differences In Increasing Vo2 Max Between Brisk Walking And High Intensity Interval Training (HIIT) In Young Adults. Jurnal Kedokteran Diponegoro, 8(4), 13561365. 
Chen, P., Mao, L., Nassis, G. P., Harmer, P., Ainsworth, B. E., \& Li, F. (2020). Wuhan coronavirus (2019-nCoV): The need to maintain regular physical activity while taking precautions. Journal of sport and health science, 9(2), 103.

Codella, R., Chirico, A., Lucidi, F., Ferrulli, A., La Torre, A., \& Luzi, L. (2020). The immune-modulatory effects of exercise should be favorably harnessed against COVID-19. Journal of Endocrinological Investigation, $1-4$. https://doi.org/10.1007/s40618-020-01403-5

da Silveira, M. P., da Silva Fagundes, K. K., Bizuti, M. R., Starck, É., Rossi, R. C., \& de Resende e Silva, D. T. (2020). Physical exercise as a tool to help the immune system against COVID-19: an integrative review of the current literature. Clinical and Experimental Medicine, 2019(0123456789). https://doi.org/10.1007/s10238-020-00650-3

Füzéki, E., \& Banzer, W. (2018). Physical activity recommendations for health and beyond in currently inactive populations. International Journal of Environmental Research and Public Health, 15(5). https://doi.org/10.3390/ijerph15051042

Guan,W.-j.,Z.-y.Ni,Y.Hu,W.-h.Liang,C.-q.Ou,J.x.He,L.Liu,H.Shan,C.-1.Lei, $\quad$ D.S.C.Hui,B. Du,L.-j.Li,G.Zeng,K.-Y. Yuen, R.-c. Chen, C.-1. Tang, T. Wang, P.y.Chen,J.Xiang,S.y.Li,J.-1.Wang,Z.-j.Liang,Y.-

x.Peng,L.Wei,Y.Liu, $\quad$ Y.h.Hu,P.Peng,J.m.Wang,J.-y.Liu,Z.Chen,G.Li,Z.-j.Zheng,S.-

q.Qiu,J.Luo,C.-j.Ye,S.-y. Zhu,andN.-s.Zhong, Clinical Characteristics of Coronavirus Disease 2019 in China. New England Journal of Medicine, 2020.

Jakobsson, J., Malm, C., Furberg, M., Ekelund, U., \& Svensson, M. (2020). Physical Activity During the Coronavirus (COVID-19) Pandemic: Prevention of a Decline in Metabolic and Immunological Functions. Frontiers in Sports and Active Living,
2(April)

https://doi.org/10.3389/fspor.2020.00057

Jesus, I., Vanhee, V., Deramaudt, T. B., \& Bonay, M. (2020). Promising effects of exercise on the cardiovascular, metabolic and immune system during COVID-19 period. Journal of Human Hypertension, 4-6. https://doi.org/10.1038/s41371-020-00416-0

Lisdiana,. (2012). REGULASI KORTISOL PADA KONDISI STRES DAN ADDICTION. Biosaintifika: Journal of Biology \& Biology Education. 4. 10.15294/biosaintifika.v4i1.2264.

Nieman, D. C., \& Wentz, L. M. (2019). The compelling link between physical activity and the body's defense system. Journal of Sport and Health Science, 8(3), 201-217. https://doi.org/10.1016/j.jshs.2018.09.009

Nurmasitoh, T. (2015). Jurnal Kedokteran dan Kesehatan Indonesia Physical activities, exercises, and their effects to the immune system. Indonesian Journal of Medicine and Health Journal, homepage(2), 52-58. www.journal.uii.ac.id/index.php/jkki

Ranasinghe, C., Ozemek, C., \& Arena, R. (2020). Exercise and well-being during COVID 19 - Time to boost your immunity. Expert Review of Anti-Infective Therapy, OO(00),

1-6. https://doi.org/10.1080/14787210.2020.17948 18

Simpson, R. J., \& Katsanis, E. (2020). The immunological case for staying active during the COVID-19 pandemic. Brain, behavior, and immunity, 87, 6-7. https://doi.org/10.1016/j.bbi.2020.04.041

Sohrabi, C., Z. Alsafi, N. O'Neill, M. Khan, A. Kerwan, A. Al-Jabir, C. Iosifidis, and R. Agha, World Health Organization declares global emergency: A review of the 2019 novel coronavirus (COVID-19). Int J Surg, 2020. 76: p. 71-76.

Wasfy, M. M., \& Baggish, A. L. (2016). Exercise Dose in Clinical Practice. 
Circulation, 133(23), 2297-2313. https://doi.org/10.1161/CIRCULATIONAHA .116 .018093

World Health Organisation, Coronavirus disease 2019 (COVID-19) Situation Report 46, 2020.

Woods, J. A., Hutchinson, N. T., Powers, S. K., Roberts, W. O., Gomez-Cabrera, M. C., Radak, Z., ... Ji, L. L. (2020). The COVID-19 pandemic and physical activity. Sports Medicine and Health Science, 2(2), 55-64. https://doi.org/10.1016/j.smhs.2020.05.006

Zhu, W. (2020). Should, and how can, exercise be done during a coronavirus outbreak? An interview with Dr. Jeffrey A. Woods. Journal of Sport and Health Science, 9(2), 105. 